\title{
Pull-down Assay on Streptavidin Beads and Surface Plasmon Resonance Chips for SWATH-MS-based Interactomics
}

\author{
JOSEF MARYÁŠ $\breve{S}^{1,2}$, JAKUB FAKTOR ${ }^{1,2}$, LENKA ČÁPKOVÁ ${ }^{1}$, \\ PETR MÜLLER $^{2}$, PETR SKLÁDAL ${ }^{1}$ and PAVEL BOUCHAL ${ }^{1}$ \\ ${ }^{I}$ Masaryk University, Faculty of Science, Department of Biochemistry, Brno, Czech Republic; \\ ${ }^{2}$ Masaryk Memorial Cancer Institute, Regional Centre for Applied Molecular Oncology, Brno, Czech Republic
}

\begin{abstract}
Background/Aim: Pul-down assay is a popular in vitro method for identification of physical interactors of selected proteins. Here, for the first time, we compared three conventional variants of pull-down assay with the streptavidinmodified surface plasmon resonance (SPR) chips for the detection of PDZ and LIM domain protein 2 (PDLIM2) interaction partners. Materials and Methods: PDLIM2 protein-protein interactions were analysed by three variants of pull-down assay on streptavidin beads using LC-MS/MS in "Sequential Window Acquisition of all Theoretical fragment ion spectra (SWATH)" mode and compared with LC-SWATHMS/MS data from SPR chips. Results: The results showed that (i) the use of SPR chip led to comparable data compared to on-column streptavidin beads, (ii) gravity flow and microflow in wash and elution steps provided better results than centrifugation, and (iii) type and concentration of detergent did not significantly affect the interactome data of cancerassociated PDLIM2. Conclusion: Our study supports further application of SPR-based affinity purification with SWATH mass spectrometry for reproducible and controlled characterization of cancer-associated interactomes.
\end{abstract}

Protein-protein interactions (PPI) play a fundamental role in a wide range of biological processes (1). Typically, proteins hardly act as isolated species while performing their functions (2); it has been revealed that over $80 \%$ of proteins do not operate alone, but in complexes (3). Therefore, the studying of

This article is freely accessible online.

Correspondence to: Pavel Bouchal, Ph.D., Masaryk University, Faculty of Science, Department of Biochemistry, Kotlarska 2, 61137 Brno, Czech Republic. Tel: +420 549493251, Fax: +420 549492690, e-mail: bouchal@chemi.muni.cz

Key Words: LC-SWATH-MS/MS, pull-down assay, PDLIM2, protein-protein interactions, SPR.
PPIs is important to infer the protein function within the cell and in the inter-cellular communication (4). The large-scale studying of affinity protein interactions is often called interactomics (5) and the importance of this field is reflected by many studies that have been performed up to now. Methods for PPIs identification can be classified according to their principles: in vitro (involving tandem affinity purification, coimmunoprecipitation and pull-down assays), in vivo (methods based on yeast two-hybrid system and synthetic lethality) and in silico (e.g. chromosome proximity, phylogenetic tree) (4). All of them have their own intrinsic advantages and disadvantages, as recently reviewed (4). This study focuses on the pull-down assay, a powerful in vitro screening tool for identifying previously unknown PPIs via an antibody-free approach $(4,5)$. To isolate and study PPIs using pull-down assay, fusion proteins of a target protein with various tags are constructed to enable capture of the target protein onto a solid support $(5,6)$. A number of affinity tags including enzymes, protein domains or small polypeptides has been developed (7). Of these, a streptavidin binding peptide (SBP)-based, 38 amino acids long tag, with high affinity to streptavidin $\left(K_{\mathrm{D}} \sim 2.5 \times 10^{-9} \mathrm{M}\right)$ enables a fast, efficient, and relatively specific one-step method for isolation and study protein complexes (8-10). Moreover, it provides better affinity, higher purity and higher yields over other commonly used tags like His tag or maltose binding protein and allows simple competitive elution by biotin under mild conditions (11) (biotin affinity to streptavidin is characterized by $K_{\mathrm{D}} \sim 1 \times 10^{-14} \mathrm{M}$ ) (9). In a practical set-up, every pull-down assay comprises five main steps: i) cell lysis, ii) capture of tagged protein onto solid support and wash off unspecific interacting biomolecules, iii) elution of specific interaction partners, iv) protein digestion and v) mass spectrometry (MS) identification and quantification of interacting partners in comparison with the control assay (Figure 1). Effectiveness of the experiment, however, always depends on the optimal binding, washing and elution conditions, and resulting specificity and compatibility for the PPIs of interest. PPIs can be also quantified using surface plasmon resonance 
Table I. Overview of methods under comparison.

\begin{tabular}{|c|c|c|c|c|}
\hline & Method 1 & Method 2 & Method 3 & Method 4 \\
\hline Lysis buffer & $\begin{array}{c}0.5 \% \text { Tween } 20, \\
150 \mathrm{mM} \mathrm{NaCl}, \\
50 \mathrm{mM} \text { HEPES } \\
\mathrm{pH} 7.5,2 \mathrm{mM} \mathrm{MgCl}{ }_{2}, \\
25 \mathrm{U} / \mu \mathrm{l} \mathrm{benzonase}, \\
\text { avidin } 10 \mu \mathrm{g} / \mathrm{ml} \text {, protease } \\
\text { and phosphatase } \\
\text { inhibitors } 10 \mu \mathrm{g} / \mathrm{ml} \text { both }\end{array}$ & 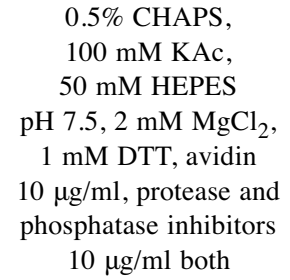 & $\begin{array}{c}0.5 \% \mathrm{NP}-40, \\
150 \mathrm{mM} \mathrm{NaCl}, \\
50 \mathrm{mM} \text { HEPES } \\
\text { pH } 7.5, \text { protease and } \\
\text { phosphatase inhibitors } \\
10 \mu \mathrm{g} / \mathrm{ml} \text { both }\end{array}$ & $\begin{array}{c}0.1 \% \text { Tween } 20, \\
150 \mathrm{mM} \mathrm{NaCl}, 50 \mathrm{mM} \\
\mathrm{HEPES} \mathrm{pH} 7.5,2 \mathrm{mM} \\
\mathrm{MgCl}_{2}, 25 \mathrm{U} / \mu \mathrm{b} \\
\text { enzonase, avidin } 10 \mu \mathrm{g} / \mathrm{ml}, \\
\text { protease and phosphatase } \\
\text { inhibitors } 10 \mu \mathrm{g} / \mathrm{ml} \text { both }\end{array}$ \\
\hline Solid support & $\begin{array}{l}\text { Streptavidin agarose } \\
\text { beads in microtube }\end{array}$ & $\begin{array}{l}\text { Streptavidin agarose } \\
\text { beads in microtube }\end{array}$ & $\begin{array}{l}\text { Streptavidin agarose } \\
\text { beads on column }\end{array}$ & $\begin{array}{l}\text { SPR streptavidin } \\
\text { chip }\end{array}$ \\
\hline $\begin{array}{l}\text { Washing and } \\
\text { elution mechanism }\end{array}$ & Centrifugation & Centrifugation & Gravity flow & Microflow \\
\hline Wash buffer & $\begin{array}{c}0.1 \% \text { Tween } 20, \\
150 \mathrm{mM} \mathrm{NaCl}, 50 \mathrm{mM} \\
\text { HEPES pH 7.5, } 2 \mathrm{mM} \\
\mathrm{MgCl}_{2}\end{array}$ & $\begin{array}{c}0.1 \% \text { CHAPS, } 100 \mathrm{mM} \\
\text { KAc, } 50 \mathrm{mM} \text { HEPES } \\
\text { pH 7.5, } 2 \mathrm{mM} \\
\mathrm{MgCl}_{2}, 1 \mathrm{mM} \mathrm{DTT}\end{array}$ & $\begin{array}{c}150 \mathrm{mM} \mathrm{NaCl}, \\
50 \mathrm{mM} \text { HEPES pH } 7.5, \\
50 \mathrm{mM} \mathrm{NaF}\end{array}$ & $\begin{array}{c}0.1 \% \text { Tween } 20,150 \mathrm{mM} \\
\mathrm{NaCl}, 50 \mathrm{mM} \\
\mathrm{HEPES} \mathrm{pH} 7.5, \\
2 \mathrm{mM} \mathrm{MgCl} 2\end{array}$ \\
\hline Elution buffer & $\begin{array}{l}\text { Wash buffer }+ \\
1 \mathrm{mM} \text { biotin }\end{array}$ & $\begin{array}{c}50 \mathrm{mM} \text { HEPES } \\
\text { pH } 7.5,100 \mathrm{mM} \\
\text { KAc, } 1 \mathrm{mM} \text { biotin }\end{array}$ & $\begin{array}{l}\text { Wash buffer }+ \\
2.5 \mathrm{mM} \text { biotin }\end{array}$ & $\begin{array}{c}0.005 \% \text { Tween } 20 \\
150 \mathrm{mM} \mathrm{NaCl}, 50 \mathrm{mM} \\
\text { HEPES pH } 7.5 \\
2 \mathrm{mM} \mathrm{MgCl}_{2}, 1 \mathrm{mM} \text { biotin }\end{array}$ \\
\hline Protein quant. & SWATH-MS & SWATH-MS & SWATH-MS & SWATH-MS \\
\hline
\end{tabular}

(SPR) $(12,13)$, which has been used almost exclusively in validation experiments with purified proteins up-to-date (1418), with a single exception (19).

PDZ and LIM domain protein 2 (PDLIM2) is a lowabundant protein that plays a role during breast cancer oncogenesis (20), with both tumour suppressor and oncoprotein contribution to breast cancer development, depending on the biological context (21). Identification of PDLIM2 interaction partners is expected to provide new insights into molecular machineries that are important in re-arrangement of the cell in various phases of tumour development. Up to now, only three studies (22-24) were focused on PDLIM2 interactome, of which two dealt with viral proteins $(22,23)$ biologically irrelevant to human background. In this study, we attempted to find optimal conditions for identification of PDLIM2 interactors by comparing four different pull-down methods (for overview see Table I) in breast cancer cells. This was represented by a stably-transfected MCF-7 breast cancer cell line expressing a fusion construct consisting of $\mathrm{N}$-terminal SBP tag and PDLIM2 or a corresponding control cell line expressing N-terminal SBP-GFP fusion protein.

\section{Materials and Methods}

Cell lines. MCF-7 breast cancer cells stably transfected with gene encoding N-terminally SBP-tagged PDLIM2 protein and control Nterminally SBP-tagged GFP protein were prepared using lentiviral vectors pLENTI-N-SBP-PDLIM2-IRES-GFP and pLENTI-N-SBP-
GFP. Lentiviral vectors were prepared in house according to Gateway ${ }^{\circledR}$ Technology with Clonase ${ }^{\circledR}$ II user guide (Invitrogen, 250749 MAN0000470). Production of lentiviruses, transduction of MCF7 cells and selection of stably transfected clones were done according to ViraPower ${ }^{\mathrm{TM}}$ Lentiviral Expression Systems user manual (Invitrogen, 25-0501 MAN0000273). Detection of recombinant proteins in selected clones was performed using SDSPAGE and western blot (see below). Each variant of cells was grown on two $15 \mathrm{~cm}$ dishes to $80 \%$ confluence in DMEM supplemented with $10 \%$ FBS, $1.25 \mathrm{mM}$ pyruvate, $0.172 \mathrm{mM}$ streptomycin, $100 \mathrm{U} / \mathrm{ml}$ penicillin and $10 \mu \mathrm{g} / \mathrm{ml}$ blasticidin. Cells were then harvested into pellet as follows: Media were aspirated from Petri dishes and attached cells were rinsed two times with cold PBS solution (2.68 $\mathrm{mM} \mathrm{KCl,} 0.137 \mathrm{M} \mathrm{NaCl}, 6.45 \mathrm{mM}$ $\mathrm{Na}_{2} \mathrm{HPO}_{4} \cdot 12 \mathrm{H}_{2} \mathrm{O}, 1.47 \mathrm{mM} \mathrm{KH} \mathrm{PO}_{4}$ ). Cells from each dish were scratched into $1 \mathrm{ml}$ cold PBS and cells of the same cell line were pooled together, transferred in a test tube, centrifuged $(5 \mathrm{~min} / 3000$ $\mathrm{g} / 4^{\circ} \mathrm{C}$ ) and the supernatant was removed.

Cell lysis. Cell lysis varied depending on the pull-down method as follows:

Method 1: Cell pellets were washed three times using wash buffer containing $0.1 \%$ Tween $20,150 \mathrm{mM} \mathrm{NaCl}, 50 \mathrm{mM}$ HEPES $\mathrm{pH} 7.5,2 \mathrm{mM} \mathrm{MgCl}{ }_{2}$ at $10,000 \times g$ for $1 \mathrm{~min}$ at RT. Washed cells were lysed by addition of $200 \mu \mathrm{l}$ ( $\sim$ three volumes) of lysis buffer (0.5\% Tween 20, $150 \mathrm{mM} \mathrm{NaCl}, 50 \mathrm{mM}$ HEPES $\mathrm{pH} 7.5,2 \mathrm{mM}$ $\mathrm{MgCl}_{2}, 25 \mathrm{U} / \mu \mathrm{l}$ benzonase, avidin $10 \mu \mathrm{g} / \mathrm{ml}$, protease and phosphatase inhibitors $10 \mu \mathrm{g} / \mathrm{ml}$ both) vortexing, centrifugation at $10,000 \times g$ for $1 \mathrm{~min}$ at RT, three times sonication at $15 \mathrm{kHz}$ frequency for five sec, and incubation for $30 \mathrm{~min}$ on ice. Cell lysates were then centrifuged at $10,000 \times \mathrm{g}$ for $15 \mathrm{~min}$ at $4^{\circ} \mathrm{C}$, supernatants were transferred to a new low-binding microtube. 


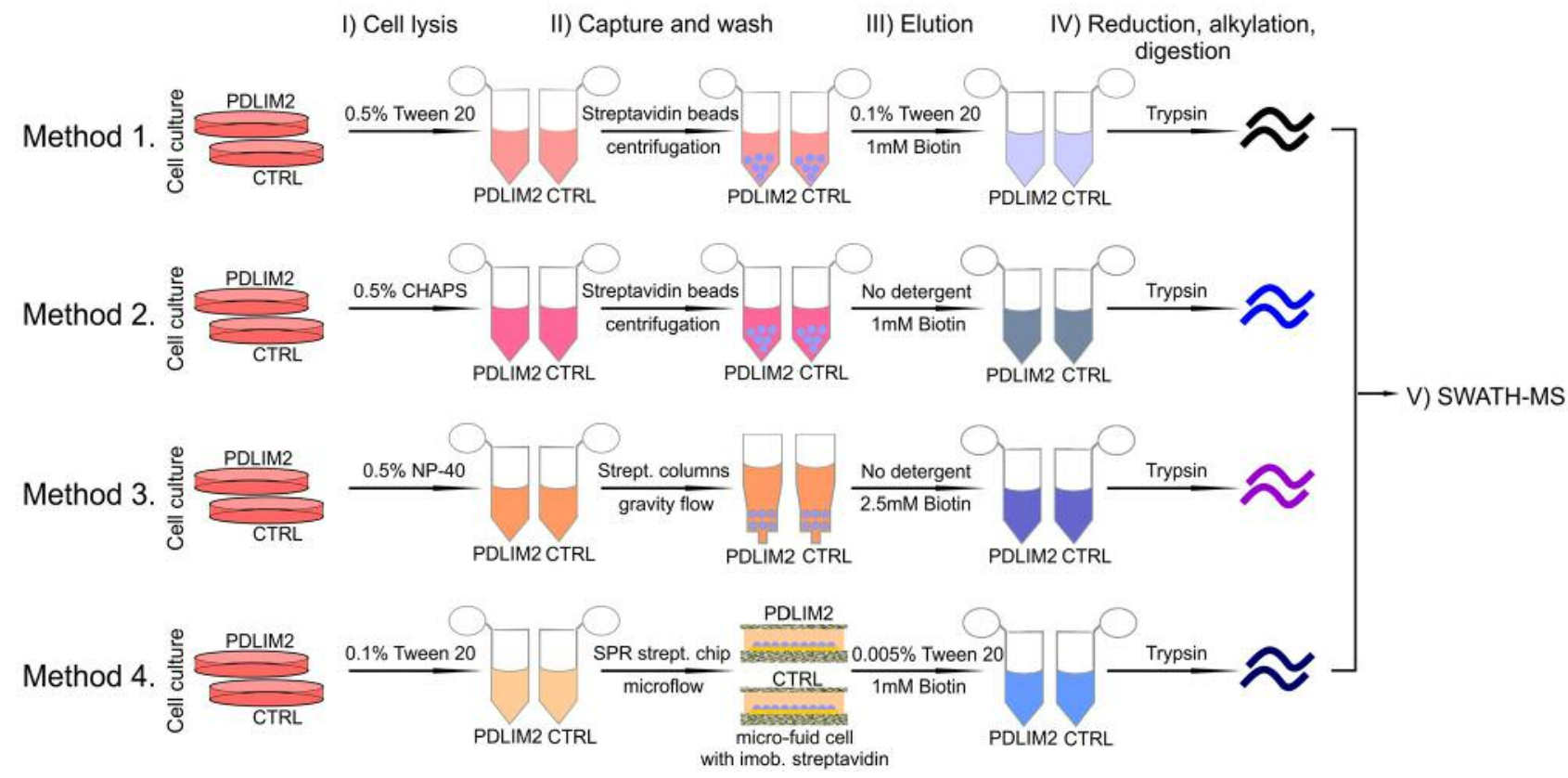

Figure 1. Overview of major steps of identification protein-protein interactions using four methods compared in this study (Methods 1-4). Individual methods differed in (i) solid supports for tagged protein capture (streptavidin agarose beads, SPR chip), (ii) mechanics of the washing and elution steps (centrifugation, gravity flow, microflow) and (iii) type and concentration of detergents (detailed in Table I). Protein quantification was performed using SWATH-MS for all methods.

Method 2: Cell lysates were prepared analogically to Method 1 with the following modifications: more effective zwitterionic detergent CHAPS was used instead of Tween 20 in lysis buffer $(0.5 \%$ CHAPS, $100 \mathrm{mM} \mathrm{KAc,} 50 \mathrm{mM}$ HEPES pH 7.5, $2 \mathrm{mM} \mathrm{MgCl} 2,1 \mathrm{mM}$ DTT, avidin $10 \mu \mathrm{g} / \mathrm{ml}$, protease and phosphatase inhibitors $10 \mu \mathrm{g} / \mathrm{ml}$ both) and in wash buffer (0.1\% CHAPS, $100 \mathrm{mM} \mathrm{KAc}, 50 \mathrm{mM}$ HEPES pH 7.5, $2 \mathrm{mM} \mathrm{MgCl}_{2}, 1 \mathrm{mM}$ DTT). Cell lysates were then centrifuged at $10,000 \times g$ for $15 \mathrm{~min}$ at $4^{\circ} \mathrm{C}$, supernatants were transferred to a new low-binding microtube.

Method 3: Unlike remaining methods, cell pellets were not washed before lysis. A total of $300 \mu \mathrm{l}$ of lysis buffer containing $0.5 \% \mathrm{NP}-40,150 \mathrm{mM} \mathrm{NaCl}, 50 \mathrm{mM}$ HEPES $\mathrm{pH} 7.5$, protease and phosphatase inhibitors $(10 \mu \mathrm{g} / \mathrm{ml}$ both) were added to pellets and incubated for $10 \mathrm{~min}$ on ice. Cell lysates were then centrifuged at $10,000 \times g$ for $20 \mathrm{~min}$ at $4^{\circ} \mathrm{C}$, supernatants were transferred to a new low-binding microtube.

Method 4: Cell lysates were prepared analogically to Method 1, however a lower, SPR compatible concentration of Tween 20 was used in lysis buffer $(0.1 \%$ Tween $20,150 \mathrm{mM} \mathrm{NaCl}, 50 \mathrm{mM}$ HEPES $\mathrm{pH} 7.5,2 \mathrm{mM} \mathrm{MgCl} 2,25 \mathrm{U} / \mu \mathrm{l}$ benzonase, avidin $10 \mu \mathrm{g} / \mathrm{ml}$, protease and phosphatase inhibitors $10 \mu \mathrm{g} / \mathrm{ml}$ both).

Total protein concentration in all lysates was determined using RC-DC Protein assay (Bio-Rad, Hercules, CA, USA) according to manufacturer's instructions and $555 \mu \mathrm{g}$ of total protein was used for each interaction assay.

Capture, wash and elution of interaction partners

Method 1: $20 \mu \mathrm{l}$ of streptavidin agarose beads (High Capacity Streptavidin Agarose Resin, Thermo Scientific, Waltham, MA, USA) were washed three times with wash buffer containing $0.1 \%$ Tween
20, $150 \mathrm{mM} \mathrm{NaCl}, 50 \mathrm{mM}$ HEPES pH 7.5, $2 \mathrm{mM} \mathrm{MgCl}_{2}$ at 10,000 $\times g$ for $1 \mathrm{~min}$ at RT and then incubated for $10 \mathrm{~min}$ on ice. A total of $555 \mu \mathrm{g}$ of total protein lysate was then added to the beads and incubated together for $1 \mathrm{~h}$ at $4^{\circ} \mathrm{C}$ on a rotating wheel. The suspension was then centrifuged at $10,000 \times g$ for $1 \mathrm{~min}$ at $4^{\circ} \mathrm{C}$, supernatants were removed and the beads were washed three times with wash buffer containing (detailed composition see above) at $10,000 \times g$ for $1 \mathrm{~min}$ at $4^{\circ} \mathrm{C}$. The beads were then incubated with $50 \mu \mathrm{l}$ elution buffer ( $1 \mathrm{mM}$ biotin, $0.1 \%$ Tween $20,150 \mathrm{mM} \mathrm{NaCl}, 50 \mathrm{mM}$ HEPES pH 7.5, $2 \mathrm{mM} \mathrm{MgCl}$ ) for $5 \mathrm{~min}$ on ice and centrifuged at $10,000 \times g$ for $1 \mathrm{~min}$ at $4^{\circ} \mathrm{C}$. Supernatants were then transferred to a new low-binding microtube.

Method 2: Each step of the procedure was analogical to Method 1 (see above); however different wash and elution buffers were used. Wash buffer was composed of $0.1 \%$ CHAPS, $100 \mathrm{mM} \mathrm{KAc}$, $50 \mathrm{mM}$ HEPES pH 7.5, $2 \mathrm{mM} \mathrm{MgCl}_{2}$ and $1 \mathrm{mM}$ DTT. Elution buffer composition was $50 \mathrm{mM}$ HEPES pH 7.5, $100 \mathrm{mM} \mathrm{KAc}$ and $1 \mathrm{mM}$ biotin.

Method 3: A volume of $100 \mu \mathrm{l}$ of streptavidin agarose beads (High Capacity Streptavidin Agarose Resin, Thermo Scientific) were equilibrated for $30 \mathrm{~min}$ on ice with $750 \mu \mathrm{l}$ lysis buffer $(0.5 \% \mathrm{NP}-40$, $150 \mathrm{mM} \mathrm{NaCl}, 50 \mathrm{mM}$ HEPES $\mathrm{pH} 7.5$, protease and phosphatase inhibitors $10 \mu \mathrm{g} / \mathrm{ml}$ both). $200 \mu \mathrm{l}$ of this slurry and $555 \mu \mathrm{g}$ of total protein lysate were then mixed in low binding microtube and incubated for $15 \mathrm{~min}$ at $4^{\circ} \mathrm{C}$ on rotating wheel. The suspension was then packed onto Bio-Spin Disposable Chromatography Columns (Bio-Rad, USA) previously washed on ice with $250 \mu$ lysis buffer (composition see above), to prevent formation of air bubbles. The beads on column were washed two times with $1 \mathrm{ml}$ lysis buffer and three times with $1 \mathrm{ml}$ wash buffer containing $150 \mathrm{mM} \mathrm{NaCl}, 50 \mathrm{mM}$ 
HEPES pH 7.5 and $50 \mathrm{mM} \mathrm{NaF}$ (gravity flow). The beads were then incubated three times on the column with $66.6 \mu$ of elution buffer containing $150 \mathrm{mM} \mathrm{NaCl}, 50 \mathrm{mM}$ HEPES pH 7.5, $50 \mathrm{mM} \mathrm{NaF}$ and $2.5 \mathrm{mM}$ biotin (gravity flow). Eluates were pooled together and transferred to a new low-binding microtube.

Method 4: The SA SPR chips (streptavidin immobilized on the CM5 carboxymethylated dextran matrix) were used with the Biacore 3000 system (GE Healthcare). The chip was equilibrated in the running buffer $(0.01 \mathrm{M}$ HEPES $\mathrm{pH} 7.4,0.15 \mathrm{M} \mathrm{NaCl}, 0.005 \%$ Tween-20, $2 \mathrm{mM} \mathrm{MgCl}$ ) for $5 \mathrm{~min}$. The flow rate $5 \mathrm{ul} / \mathrm{min}$ was always used. A zone of the total protein lysate $(555 \mu \mathrm{g})$ diluted twice in the running buffer (composition see above) was then injected and allowed to interact in flow for $10 \mathrm{~min}$. The chip was washed for $10 \mathrm{~min}$, the mean bound amount was $183 \pm 19 \mathrm{RU} ; 1 \mathrm{RU}$ was stated to be approximately equivalent to a change in surface concentration of $1 \mathrm{pg} / \mathrm{mm}^{2}$ (anon, Biacore Assay Handbook, GE Healthcare, Piscataway, NJ 2012, p. 9). Then, elution buffer (0.01 M HEPES pH 7.4, 0.15 M NaCl, 0.005\% Tween-20, $2 \mathrm{mM}$ $\mathrm{MgCl}_{2}, 1 \mathrm{mM}$ biotin) was injected and stopped inside the flow cell for $2 \mathrm{~min}$. The eluted proteins $(7 \mu \mathrm{l})$ were captured in a vial and frozen. The mean unbound amount was $166 \pm 80 \mathrm{RU}$. The whole process was controlled by a custom script based on the MICRORECOVER procedure from the Biacore programming language. Finally, the chip was washed twice with $10 \mathrm{mM} \mathrm{NaOH}$ ( 2 min pulses) and for 5 min with the running buffer (composition see above). An example sensorgram from this procedure is provided in Figure 2.

Proteomic identification of protein-protein interacting partners: protein digestion. Proteins were digested with trypsin using filter aided sample preparation and desalted using C18 spin columns as previously described (25) and dried under vacuum.

$L C-M S / M S$. Prior to the analysis, the dried peptides were dissolved in $40 \mu \mathrm{l}$ of $5 \%$ acetonitrile, $0.05 \%$ TFA. A volume of $0.8 \mu \mathrm{l}$ of $1 \mathrm{x}$ HRM peptides (Biognosys, Zurich, Switzerland) was added and $4 \mu \mathrm{l}$ of the resulting solution was loaded on LC-MS/MS. Tryptic digests were separated on Eksigent Ekspert nanoLC 400 liquid chromatography (SCIEX, Dublin, CA, USA) on-line coupled to TripleTOF 5600+ (SCIEX, Toronto, Canada) mass spectrometer. Sample pre-concentration and desalting was performed on a cartridge trap column $(300 \mu \mathrm{m}$ i.d. $\times 5 \mathrm{~mm})$ packed with $\mathrm{C} 18$ PepMap100 sorbent with $5 \mu \mathrm{m}$ particle size (Thermo Scientific) using a mobile phase composed from $0.05 \%$ trifluoroacetic acid (TFA) in $2 \%$ acetonitrile (ACN). Subsequently, peptides were separated on a capillary analytical column $(75 \mu \mathrm{m}$ i.d. $\times 500 \mathrm{~mm})$ packed with C18 PepMap100 sorbent, $2 \mu \mathrm{m}$ particle size (Thermo Fisher Scientific, Waltham, MA, USA). Mobile phase A composed of $0.1 \%(\mathrm{v} / \mathrm{v})$ formic acid (FA) in water while mobile phase B composed of $0.1 \%(\mathrm{v} / \mathrm{v})$ FA in ACN. Analytical gradient started from $2 \% \mathrm{~B}$, the proportion of mobile phase B increased linearly up to $40 \% \mathrm{~B}$ in $120 \mathrm{~min}$, flow was $300 \mathrm{nl} / \mathrm{min}$. The analytes were ionized in nano-electrospray ion source, where nitrogen was used as a drying and nebulizing gas. Temperature and flow of drying gas was set to $150^{\circ} \mathrm{C}$ and $12 \mathrm{psi}$. Voltage at the capillary emitter was $2.65 \mathrm{kV}$.

Data acquisition in data-dependent mode. To generate a SWATH assay library, a pooled mixture of all digested protein samples was measured in a positive data dependent acquisition (DDA) mode in three technical replicates (injections). Up to 20 most intensive precursor ions with intensity exceeding $50 \mathrm{cps}$ were fragmented in each cycle. Cycle time was $2.3 \mathrm{sec}, \mathrm{m} / \mathrm{z}$ range was set to $400-1250$ for MS and 200-1600 for MS/MS. Precursor exclusion time was set to $12 \mathrm{sec}$.

Data acquisition in data independent SWATH mode. All digested eluates were measured in a positive high sensitivity product ion scan in two technical replicates (injections). Precursor ion range was set from $\mathrm{m} / \mathrm{z}, 400$ up to 1200 and further divided into 67 SWATH windows, each 12 Da wide with 1 Da overlap. Accumulation time per SWATH window was $50.8 \mathrm{msec}$, resulting in $3.5 \mathrm{sec}$ cycle time. Rolling collision energy with $15 \mathrm{~V}$ spread was set. Product ions were scanned from $360 \mathrm{~m} / \mathrm{z}$ up to $1360 \mathrm{~m} / \mathrm{z}$.

Data processing. Protein identification in DDA runs was performed with MaxQuant 1.5.3.30 (www.maxquant.org) using Andromeda database search algorithm against UniProt/SwissProt human database version 2015_02 downloaded on 19.3.2015 containing 20,198 sequences, complemented by iRT protein database (Biognosys, Zurich, Switzerland) and internal database of common protein contaminants in Andromeda, using default settings for Sciex Q-TOF instrument. Enzyme name: Trypsin (cleaving polypeptides at the carboxyl side of lysine or arginine except when either is followed by proline), max. missed cleavage sites: 2, taxonomy: Homo sapiens. Decoy database search: True. PSM FDR 0.01, protein FDR 0.01, site FDR 0.01 Tolerances: precursor mass tolerance $0.07 \mathrm{Da} / 0.006 \mathrm{Da}$ (first search/main search), fragment mass tolerance $40 \mathrm{ppm}$. Modifications: Dynamic (variable): Oxidation (M); Acetyl (Protein N-term). Static (fixed): Carbamidomethyl (C). SWATH assay library was generated in Spectronaut 8.0 software (Biognosys, Zurich, Switzerland) based on the results of MaxQuant database search of all DDA analyses. Quantitative peptide level information was extracted from SWATH data using Spectronaut 8.0, the peptides detected significantly $(\mathrm{q}<0.01)$ at least once across all SWATH runs were involved in the final dataset ("Qvalue sparse" setting in Spectronaut software). The quantitative information was extracted for all corresponding proteins/peptides/transitions and for all conditions using algorithm implemented in Spectronaut, with data normalization between runs. Statistical analysis of intensities of all proteins identified at least once across the SWATH dataset with q-value $<0.01$ was performed in mapDIA 2.3.1 software at fragment level as follows: The data was $\log 2$ transformed, normalized by dividing by the total intensity sum and analyzed in "ReplicateDesign" setting. Only peptides with 3 to 6 fragments were used, data from 1 to 5 peptides per protein were used for protein level quantification, standard deviation factor was set to 2 and minimal intra-protein correlation of peptides was set to 0.2 .

SDS-PAGE and western blotting. SDS-PAGE and western blotting were used to determine the expression of PDLIM2 and streptavidin binding peptide fusion protein in the cells. Cell lysates were prepared using hot $\left(95^{\circ} \mathrm{C}\right)$ sample buffer $(10 \%$ glycerol, $2 \%$ bromophenol blue, $62.5 \mathrm{mM}$ Tris $\mathrm{HCl} \mathrm{pH} 6.8,2 \% \mathrm{SDS} \mathrm{pH} 6.8,5 \%$ mercaptoethanol). SDS-PAGE with 5\% stacking gel (126.67 mM Tris $\mathrm{HCl} \mathrm{pH} 6.8,5 \%$ acrylamide, $0.6 \%$ TEMED, $1.2 \%$ APS) and $10 \%$ running gels $(373 \mathrm{mM}$ Tris $\mathrm{HCl} \mathrm{pH} 6.8,10 \% \mathrm{M}$ acrylamide, $0.6 \%$ TEMED, $1.2 \%$ APS) were used for separation. $20 \mu \mathrm{g}$ of total protein as determined by RC-DC Protein Assay (Bio-Rad) were run 


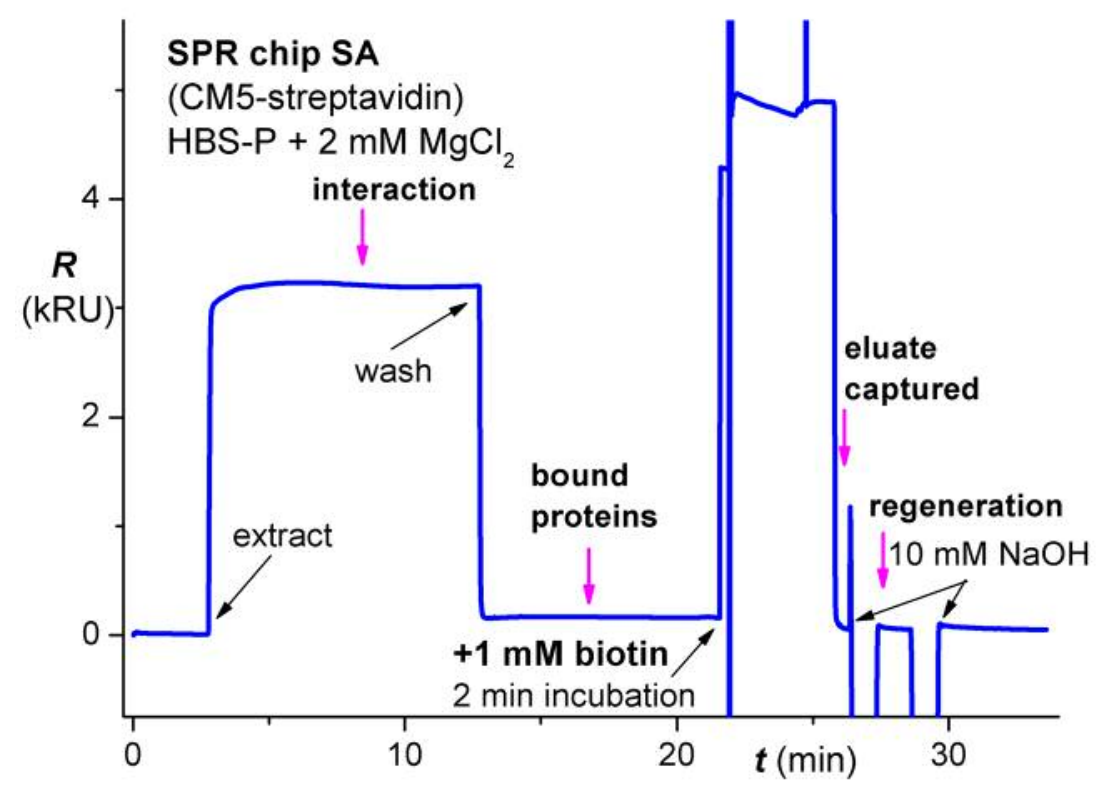

Figure 2. Typical sensorgram from interaction of the lysate with streptavidin-modified SPR chip and elution of the captured proteins using the MICRORECOVERY procedure of Biacore.

in gels and wet transferred onto PVDF membranes. Membranes were than blocked for $1 \mathrm{~h}$ in PBS+0.1\% Tween $20(2.68 \mathrm{mM} \mathrm{KCl}$, $0.137 \mathrm{M} \mathrm{NaCl}, 6.45 \mathrm{mM} \mathrm{Na}_{2} \mathrm{HPO}_{4} .12 \mathrm{H}_{2} \mathrm{O}, 1.47 \mathrm{mM} \mathrm{KH}_{2} \mathrm{PO}_{4}$, $0.89 \mathrm{mM}$ Tween 20) containing $5 \%$ non-fat milk, washed two times in PBS and once in PBS+0.1\% Tween 20 and incubated with primary antibody in $4{ }^{\circ} \mathrm{C}$ overnight. Mouse anti-PDLIM2 antibody (OriGene Cat. No TA50270, dilution 1:250) was used for PDLIM2 detection, Streptavidin-Peroxidase polymer (Sigma-Aldrich Cat. No. S2438-250UG, dilution 1:2,000) was used for SBP detection and in-house prepared PC10 antibody supernatant in dilution corresponding to concentration $1 \mu \mathrm{g} / \mathrm{ml}$ was used to detect proliferating cell nuclear antigel (PCNA) as a loading control. After the incubation, membranes were washed again. Membranes incubated with anti-PDLIM2 antibody or PC10 antibody supernatant were subsequently incubated with corresponding secondary antibody (RAMPx, DakoCytomation, dilution 1:1,000) at room temperature for $1 \mathrm{~h}$. After incubation with secondary antibody, the membranes were washed again and incubated for 5 min with enhanced chemiluminescence (ECL) solution $(10 \mathrm{mM}$ luminol, $0.5 \mathrm{mM}$ EDTA, $405 \mu \mathrm{M}$ coumaric acid, $200 \mathrm{mM}$ Tris $\mathrm{pH}$ 9.4, $8 \mathrm{mM}$ sodium perborate tetrahydrate, $50 \mathrm{mM}$ sodium acetate $\mathrm{pH}$ 5). Membranes incubated with Streptavidin-Peroxidase polymer were directly incubated with ECL solution for $5 \mathrm{~min}$. In both cases, immunoreactive proteins were visualized by ECL using CCD camera.

\section{Results}

To identify PDLIM2 interacting partners in human breast cancer cells, we generated a cell line stably transfected with sequences encoding N-terminally SBP tagged PDLIM2 protein as well as control cell line stably transfected with sequences encoding SBP tagged green fluorescence protein
(GFP). Expression of PDLIM2 and SBP was confirmed using western blotting as shown in Figure 3. To compare different experimental conditions that may play a role in identification of PDLIM2 interactors, we used four different pull-down assay protocols adopted and/or modified from previous publications: Method 1 (26) and Method 3 (27), of which the first one was also modified by the use of zwitterionic detergent (28) (Method 2) and for the use on SPR chip (Method 4), see Figure 1 and Table I for overview of the details. In all methods, the eluted proteins were reduced, alkylated, digested by trypsin and the resulting peptides were analysed by LC-MS/MS in SWATH mode to ensure consistent peptide and protein quantification across the samples (27), with quantitative data extraction in Spectronaut software (29) using a custom spectral library containing 128 identified protein groups based on 675 peptides. Quantitative data were obtained for 120 consistently quantified proteins across SWATH dataset that were statistically evaluated in mapDIA software (30) (see Materials and Methods for details). Importantly, significantly high augmentation of PDLIM2 protein levels were detected by all four methods. Among them, the highest $\log 2$ fold change $\left(\log _{2} \mathrm{FC}\right)$ of PDLIM2 protein against control pulldown assay, $\log _{2} \mathrm{FC}=7.692$, was obtained by Method 3, originating from both the highest signal in PDLIM2-positive sample ( $\log 2$ protein intensity was 5.007$)$ and the lowest one in a control sample ( -2.766 , Table II). This was followed by $\log _{2} \mathrm{FC}$ obtained by Method $2\left(\log _{2} \mathrm{FC}=3.049\right)$, Method 4 $\left(\log _{2} \mathrm{FC}=2.578\right)$ and Method $1\left(\log _{2} \mathrm{FC}=1.590\right)$. 


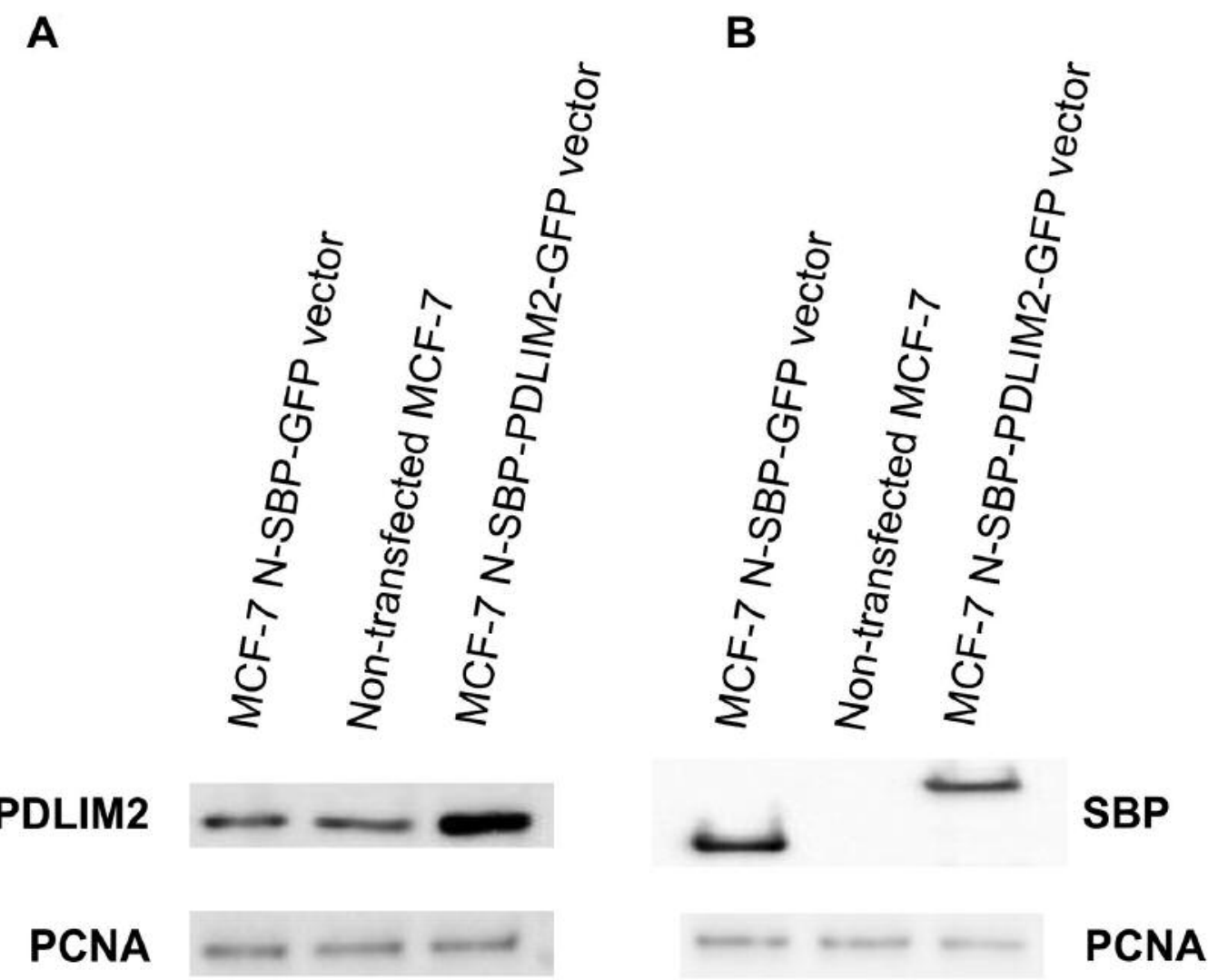

Figure 3. Verification of successful incorporation of pLENTI-N-SBP-PDLIM2-IRES-GFP and pLENTI-N-SBP-GFP vectors in MCF7 cells. A) Detection of PDLIM2 protein levels in non-transfected MCF7 cells and stably transfected MCF7 N-SBP-PDLIM2 cells and MCF7 N-SBP-GFP cells. B) Detection of Streptavidin-binding peptide in non-transfected MCF7 cells and stably-transfected MCF7 N-SBP-PDLIM2 cells and MCF7 $N$-SBP-GFP cells. Proliferating cell nuclear antigen (PCNA) was used as a loading control.

As biologically relevant interacting protein partners we considered only proteins statistically significantly more abundant $\left(\log _{2} \mathrm{FC}>1\right.$ and FDR $\left.<0.05\right)$ in PDLIM2 positive purifications by at least two methods in parallel (see Table II). This provides an initial validation corresponding to the technical aims of this study. The largest overlap (6 interactors) was found between Method 3 and Method 4, involving biologically interesting interactions with Shroom3 (SHROOM3), serine/threonine protein kinase Nek 10 (NEK10) and CREB3 regulatory factor (CREBRF). A single interaction confirmed by both Method 1 and Method 4 was between PDLIM2 and calmodulin. These proteins may represent novel potential interaction partners of PDLIM2 in breast cancer cells. Interestingly, additional interactors that support previously identified PDLIM2 interactions with stress fibres (actin, tropomyosin alpha-3 chain, transgelin-2 and contractility regulator calmodulin) were confirmed almost exclusively by SPR-chip based Method 4 as shown in Table III.

\section{Discussion}

In this study, we attempted to find optimal conditions for identification of PDLIM2 interactors in breast cancer background drawing a comparison between three conventional pull-down-LC-MS/MS approaches and pulldown assay on the streptavidin-modified SPR chips. We mainly focused on the following key steps: (i) solid support on which the fusion proteins are bound, (ii) the mechanics of the washing and elution, and (iii) detergents used for cell lysis, wash and elution of interacting proteins.

Our data show that both types of solid support, streptavidin beads and SPR chip, enabled a sufficient capacity to bind, identify and quantify SBP-PDLIM2 protein using pull-down MS approach because significant augmentation of PDLIM2 protein levels was detected by all four methods (see $\log 2 \mathrm{FC}$ values in Table II). This is especially important for the SPR chip, whose capacity is considered significantly lower than the capacity of the 


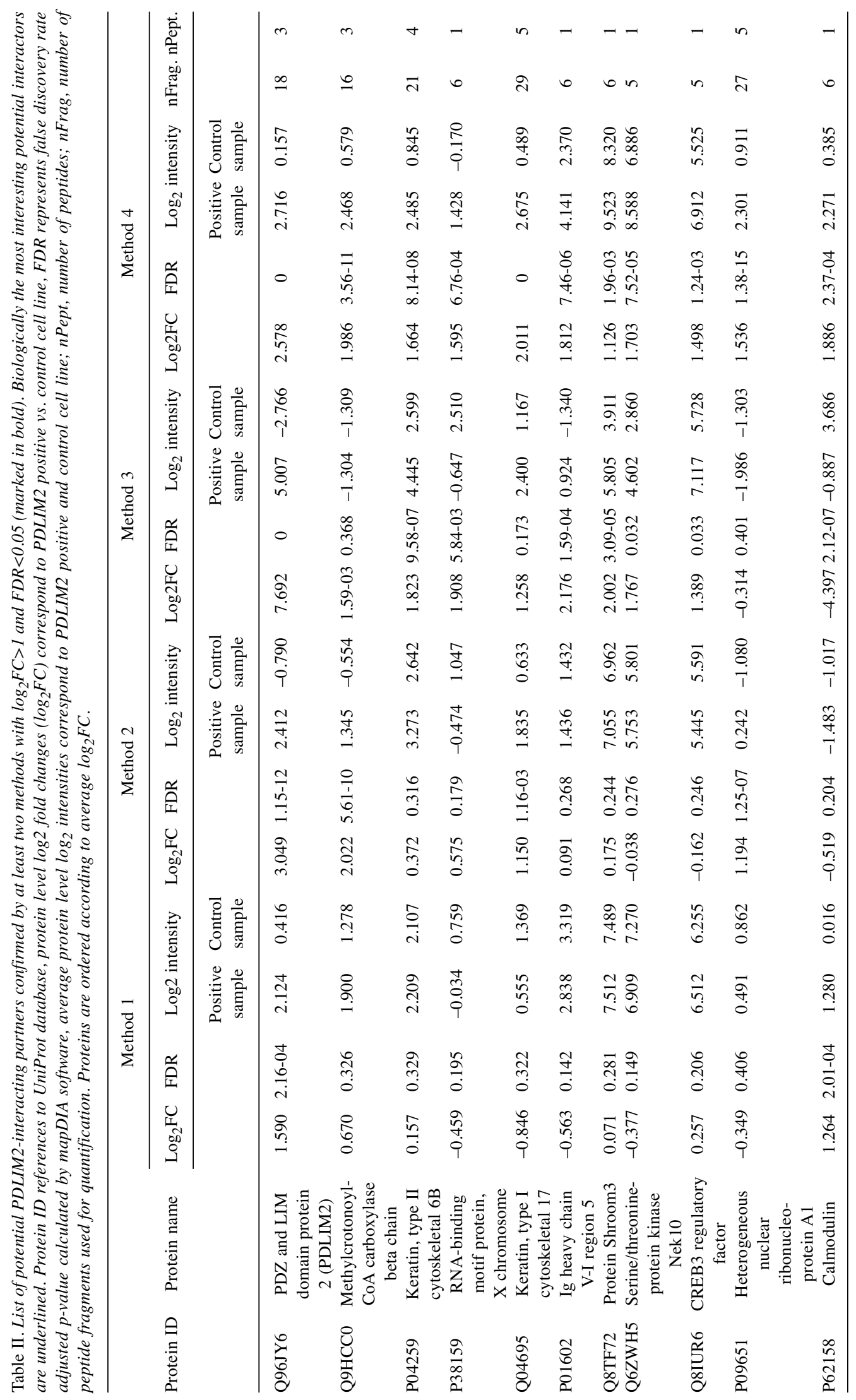


streptavidin beads. An important difference between Method 3 (that provided both the highest $\log _{2} \mathrm{FC}$ and PDLIM2 protein intensities) $v s$. Methods 2 and 1 was the use of different mechanics of wash and elution, which was done by gravity flow in Method 3, while by centrifugation in Methods 1 and 2. Also, Method 4 based on SPR chip and micro-flow provided very similar data as Methods 1 and 2 in term of signal intensities of PDLIM2, despite the lower binding capacity of SPR chip. However, signal intensities of many potential interactors in Method 4 were comparable or higher than in Method 3, which may indicate comparable or even better binding conditions for some specific proteins in Method 4 than in Method 3 (Table II). Importantly, Method 1 and Method 4 provided different potential interactors. Since they were based on similar lysis, wash and elution buffers but different solid support and mechanics of elution, we conclude that buffer composition has only a minor effect on our results, in contrast to solid support and mechanics of elution, where gravity flow and microflow provided better results than centrifugation. From the practical point of view, lower sample consumption, time-saving, and more efficient binding conditions are the major benefits of SPR. The fully automated operation significantly enhancing reproducibility of assays and minimized workload represent additional experimental benefits of the use of SPR chip.

In the next step, we focused on biological relevance of our data. Only proteins statistically significantly more abundant $(\log 2 \mathrm{FC}>1$ and FDR $<0.05)$ in PDLIM2 positive purifications by at least two methods in parallel were considered as a biologically relevant and among them SHROOM3, CREBRF, NEK10 and calmodulin were detected. SHROOM3 is involved in Rho signalling and epithelial cell remodelling (31), CREBRF regulates NF-KB pathway via CREB3 protein (32), NEK10 regulates MAPK pathway (33) and regulates phosphorylation-mediated contractility of stress fibres (34). However, all potential interactions detected in screening experiments such as APMS generally require further validation using an independent approach before considered as "true" interactions. Our data also correspond to previously published PDLIM2 interactors: Torrado et al. (24) identified components of stress fibres, including filamin A, as PDLIM2 interactors. Filamin A and other components of stress fibres (actin (35), tropomyosin alpha-3 chain, transgelin-2 and contractility regulator calmodulin) were detected by Method 4 (see Table III), which further supports PDLIM2 interaction with stress fibre proteins and thus biological relevance of our data.

In conclusion, we for the first time compared conventional pull-down-LC-MS/MS approaches with SPR-LC-MS/MS system. Both pull-down-LC-SWATH-MS/MS approach with gravity flow and SPR-LC-SWATH-MS/MS system represent

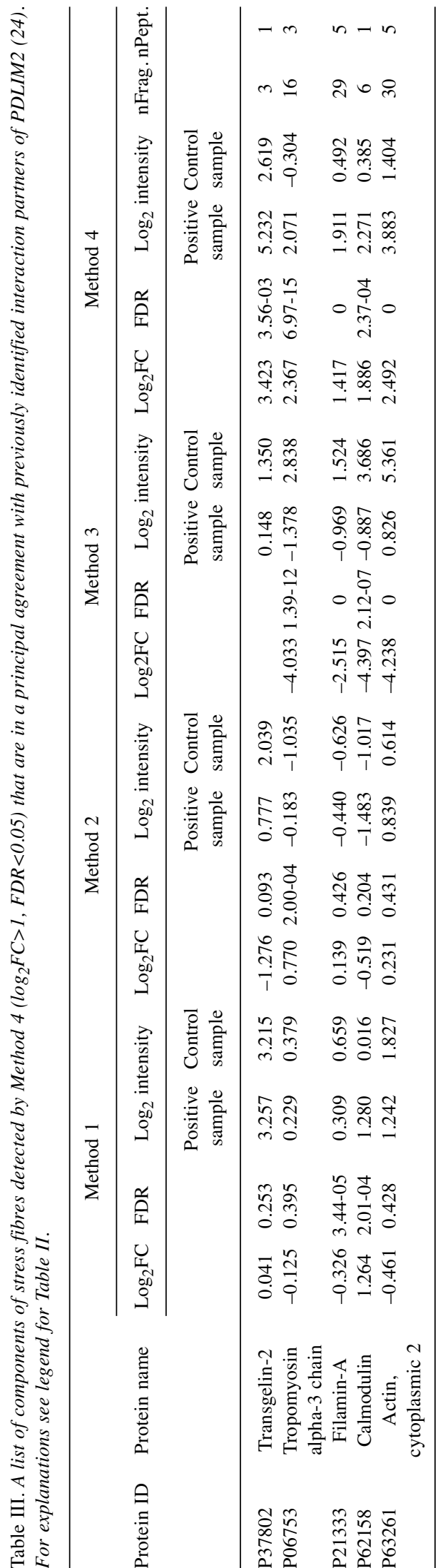


potent tools in interactomics studies, where SWATH-MS enables consistent and reliable protein quantification $(27$, 36). Moreover, the SPR-based system provides efficient binding conditions, real-time observation of binding/ washing/elution steps and fully automated operation, which do not exist in the alternative procedures.

\section{Conflicts of Interest}

The Authors have declared no conflicts of interest.

\section{Acknowledgements}

This work was supported by Czech Science Foundation (Project No. 17-05957S), JM and JF were supported by grant MEYS-NPS-LO1413.

\section{References}

1 Braun P and Gingras AC: History of protein-protein interactions: from egg-white to complex networks. Proteomics 12: 14781498, 2012.

2 Yanagida M: Functional proteomics; current achievements. J Chromatogr B Analyt Technol Biomed Life Sci 771: 89-106, 2002.

3 Berggard T, Linse S and James P: Methods for the detection and analysis of protein-protein interactions. Proteomics 7: 28332842, 2007.

4 Rao VS, Srinivas K, Sujini GN and Kumar GN: Protein-protein interaction detection: methods and analysis. Int $\mathrm{J}$ Proteomics 2014: 147648, 2014.

5 Kool J, Jonker N, Irth H and Niessen WM: Studying proteinprotein affinity and immobilized ligand-protein affinity interactions using MS-based methods. Anal Bioanal Chem 402: 1109-1125, 2011.

6 Takahashi N, Kaji H, Yanagida M, Hayano T and Isobe T: Proteomics: advanced technology for the analysis of cellular function. J Nutr 133: 2090-2096, 2003.

7 Zhao X, Li G and Liang S: Several affinity tags commonly used in chromatographic purification. J Anal Methods Chem 2013: 581093, 2013.

8 Barrette-Ng IH, Wu SC, Tjia WM, Wong SL and Ng KK: The structure of the SBP-Tag-streptavidin complex reveals a novel helical scaffold bridging binding pockets on separate subunits Acta Crystallogr D Biol Crystallogr 69: 879-887, 2013.

9 Wu SC and Wong SL: Structure-guided design of an engineered streptavidin with reusability to purify streptavidin-binding peptide tagged proteins or biotinylated proteins. PLoS One 8 : e69530, 2013.

10 Stotland A, Pruitt L, Webster P and Wolkowicz R: Purification of the COP9 signalosome complex and binding partners from human T cells. OMICS 16: 312-319, 2012.

11 Keefe AD, Wilson DS, Seelig B and Szostak JW: One-step purification of recombinant proteins using a nanomolar-affinity streptavidin-binding peptide, the SBP-Tag. Protein Expr Purif 23: 440-446, 2001.

12 Wang DS and Fan SK: Microfluidic Surface Plasmon Resonance Sensors: From Principles to Point-of-Care Applications. Sensors (Basel) 16: e1175, 2016.
13 Stockley PG and Persson B: Surface plasmon resonance assays of DNA-protein interactions. Methods Mol Biol 543: 653-669, 2009.

14 Borch J and Roepstorff P: Combinations of SPR and MS for characterization of native and recombinant proteins in cell lysates. Mol Biotechnol 33: 179-190, 2006.

15 Reverté L, de la Iglesia P, del Río V, Campbell K, Elliott CT, Kawatsu K, Katikou P, Diogène J and Campàs M: Detection of tetrodotoxins in puffer fish by a self-assembled monolayer-based immunoassay and comparison with surface plasmon resonance, LCMS/MS, and mouse bioassay. Anal Chem 87: 10839-10847, 2015.

16 Nedelkov D, Tubbs KA and Nelson RW: Surface plasmon resonance-enabled mass spectrometry arrays. Electrophoresis 27 : 3671-3675, 2006.

17 Boucher LE and Bosch J: Development of a multifunctional tool for drug screening against plasmodial protein-protein interactions via surface plasmon resonance. J Mol Recognit 26: 496-500, 2013.

18 Bécsi B, Dedinszki D, Gyémánt G, Máthé C, Vasas G, Lontay $\mathrm{B}$ and Erdődi F: Identification of protein phosphatase interacting proteins from normal and UVA-irradiated $\mathrm{HaCaT}$ cell lysates by surface plasmon resonance based binding technique using biotinmicrocystin-LR as phosphatase capturing. molecule. J Photochem Photobiol B 138: 240-248, 2014.

19 Hayano T, Yamauchi Y, Asano K, Tsujimura T, Hashimoto S, Isobe T and Takahashi N: Automated SPR-LC-MS/MS system for protein interaction analysis. J Proteome Res 7: 4183-4190, 2008.

20 Bouchal P, Dvořáková M, Roumeliotis T, Bortliček Z, Ihnatová I, Procházková I, Ho JT, Maryáš J, Imrichová H, Budinská E, Vyzula R, Garbis SD, Vojtěšek B and Nenutil R: Combined Proteomics and Transcriptomics Identifies Carboxypeptidase B1 and Nuclear Factor $\mathrm{kB}$ (NF-kB) Associated Proteins as Putative Biomarkers of Metastasis in Low Grade Breast Cancer. Mol Cell Proteomics 14: 1814-1830, 2015.

21 Maryas J and Bouchal P: PDLIM2 and its Role in Oncogenesis Tumor Suppressor or Oncoprotein? Klin. Onkol 28: 40-46, 2015.

22 Yu J, Li X, Wang Y, Li B, Li H, Li Y, Zhou W, Zhang C, Wang Y, Rao Z, Bartlam M and Cao Y: PDlim2 selectively interacts with the PDZ binding motif of highly pathogenic avian H5N1 influenza A virus NS1. PLoS One 6: e19511, 2011.

$23 \mathrm{Fu}$ J, Yan P, Li S, Qu Z and Xiao G: Molecular determinants of PDLIM2 in suppressing HTLV-I Tax-mediated tumorigenesis. Oncogene 29: 6499-6507, 2010.

24 Torrado M, Senatorov VV, Trivedi R, Fariss RN and Tomarev SI: Pdlim2, a novel PDZ-LIM domain protein, interacts with alpha-actinins and filamin A. Invest Ophthalmol Vis Sci 45: 3955-3963, 2004.

25 Dvořáková $\mathrm{M}$, Jeřábková $\mathrm{J}$, Procházková I, Lenčo J, Nenutil R and Bouchal P: Transgelin is upregulated in stromal cells of lymph node positive breast cancer. J Proteomics 132: 103-111, 2016.

26 Trcka F, Durech M, Man P, Hernychova L, Muller P and Vojtesek B: The assembly and intermolecular properties of the Hsp70-Tomm34-Hsp90 molecular chaperone complex. J Biol Chem 289: 9887-9901, 2014.

27 Collins BC, Gillet LC, Rosenberger G, Röst HL, Vichalkovski A, Gstaiger M and Aebersold R: Quantifying protein interaction dynamics by SWATH mass spectrometry: application to the 143-3 system. Nat Methods 10: 1246-1253, 2013. 
28 Görg A, Weiss W and Dunn MJ: Current two-dimensional electrophoresis technology for proteomics. Proteomics 4: 36653685, 2004.

29 Bruderer R, Bernhardt OM, Gandhi T, Miladinović SM, Cheng LY, Messner S, Ehrenberger T, Zanotelli V, Butscheid Y, Escher $\mathrm{C}$, Vitek O, Rinner $\mathrm{O}$ and Reiter L: Extending the limits of quantitative proteome profiling with data-independent acquisition and application to acetaminophen-treated threedimensional liver microtissues. Mol Cell Proteomics 14: 14001410, 2015.

30 Teo G, Kim S, Tsou CC, Collins B, Gingras AC, Nesvizhskii AI and Choi H: mapDIA: Preprocessing and statistical analysis of quantitative proteomics data from data independent acquisition mass spectrometry. J Proteomics 129: 108-120, 2015.

31 Nishimura T and Takeichi M: Shroom3-mediated recruitment of Rho kinases to the apical cell junctions regulates epithelial and neuroepithelial planar remodeling. Development 135: 1493$1502,2008$.

32 Xue H, Zhang J, Guo X, Wang J, Li J, Gao X, Guo X, Li T, Xu S, Zhang P, Liu Q and Li G: CREBRF is a potent tumor suppressor of glioblastoma by blocking hypoxia-induced autophagy via the CREB3/ATG5 pathway. Int J Oncol 49: 519528,2016
33 Moniz LS and Stambolic V: Nek10 mediates $\mathrm{G}_{2} / \mathrm{M}$ cell cycle arrest and MEK autoactivation in response to UV irradiation. Mol Cell Biol 31: 30-42, 2011.

34 Tojkander S, Gateva G and Lappalainen P: Actin stress fibers-assembly, dynamics and biological roles. J Cell Sci 125: 18551864, 2012.

35 Arany I, Clark JS, Reed DK, Ember I and Juncos LA: Cisplatin enhances interaction between p66Shc and HSP27: its role in reorganization of the actin cytoskeleton in renal proximal tubule cells. Anticancer Res 32: 4759-4763, 2012.

36 Gillet LC, Navarro P, Tate S, Röst H, Selevsek N, Reiter L, Bonner R and Aebersold R: Targeted data extraction of the MS/MS spectra generated by data-independent acquisition: a new concept for consistent and accurate proteome analysis. Mol Cell Proteomics 11: O111.016717, 2012.
Received July 4, 2018

Revised July 26, 2018

Accepted July 27, 2018 